Tetiana M. Tkachenko, Doctor of technical sciences, Professor of the Department of Labor Protection and Environment

ORCID: orcid. org/ 0000-0003-2105-5951,e-mail: tkachenkoknuba@gmail.com

Ivan O. Prokopenko, student of the Department of Labor Protection and Environment $\boldsymbol{e}$-mail: vanya.prokopenko.2001@gmail.com

Kyiv National University of Construction and Architecture, Kyiv, Ukraine

\title{
CALCULATION OF MAINTENANCE OF SURFACE DRAINAGE ROOFING OF A GERMAN MANUFACTURER
}

\begin{abstract}
With the help of some green technologies, such as green roofs, quantitative and qualitative indicators of rainwater can be successfully adjusted. The big advantage of green roofs is the accumulation of moisture, which allows to delay the runoff of storm water, unloading the sewer system and preventing floods. However, an arbitrary increase in accumulated water in a standard green roof structure is not possible, because more amount of moisture can adversely affect vegetation. However, this option is available in the rainwater system on the green roof as an addition to other landscaping systems. The rainwater collection system on the green roof allows to accumulate on average $80 \mathrm{l} / \mathrm{m}^{2}$ of rainfall and then release water into the sewer system for a certain period of time (from 24 hours to several days). The purpose of the study - to study the effect of surface runoff on the environment and reduce its negative impact with the help of green roofs. The calculation of the retained surface runoff by the roof of the German manufacturer was carried out according to the original author's method (Tkachenko, T., 2019). The reservoir volume was calculated using the author's advanced Wilo methodology adapted to the climatic conditions of Ukraine. The calculation of the retained surface runoff is done by the roof of the German manufacturer ZinCo. The "green" roof is located in Kiev. The area of the roof is $150 \mathrm{~m}^{2}$. ZinCo roof has been found to be able to hold 7950 liters of rainwater and thereby to reduce surface runoff by unloading storm wells. Roof efficiency for the reduction of surface runoff reaches $21.2 \%$, which is a very good indicator. Purified rain water from green roofs can be collected in tanks and used for technical purposes. For collecting rain water from an intensive flat roof with an area of $150 \mathrm{~m}^{2}$, a $4 \mathrm{~m}^{3}$ tank is needed for an office staff of 8 people.
\end{abstract}

Keywords: surface runoff; "green" roof; rain water; storage tank

\section{Т.М. Ткаченко, І.О. Прокопенко}

Київський національний університет будівництва і архітектури, м. Київ, Україна

\section{РОЗРАХУНОК УТРИМАНОГО ПОВЕРХНЕВОГО СТОКУ ПОКРІВЛЕЮ НІМЕЦЬКОГО ВИРОБНИКА}

Анотація. За допомогою деяких «зелених» технологій, наприклад «зелених» дахів, можна успішно регулювати кількісні на якісні показники дощових стічних вод. Великою перевагою «зелених» дахів є накопичення вологи, що дозволяє відстрочити стік зливової води, розвантажуючи при цьвому каналізаційну систему $і$ попереджаючи повені. Однак довільне збільшення накопичуваної води в стандартній структурі «зеленого» даху неможливо, оскільки більша кількість вологи може згубно вплинути на рослинність.

(C) Т.М. Ткаченко, I.О. Прокопенко, 2020

ISSN: 2411-4049. Екологічна безпека та природокористування, № 3 (35), 2020 
Проте, така опиія доступна в системі дощової води на «зеленій» покрівлі в якості доповнення до інших систем озеленення. Система збору дощової води на «зеленій» покрівлі дозволяє накопичити в середньому до $80 \mathrm{r} / \mathrm{M}^{2}$ опадів, а потім протягом певного, визначеного заздалегідь періоду (від 24 годин до декількох днів) вивільнити воду в каналізаційну систему. Мета роботи дослідження впливу поверхневого стоку на навколишнє середовище та зменшення його негативного впливу за допомогою «зелених» покрівель. Розрахунок утриманого поверхневого стоку покрівлею німеиького виробника здійснювався за оригінальною авторською методикою (Ткаченко, T., 2019). Розрахунок об'єму резервуара здійснювався за удосконаленою автором методикою на базі методики Wilo, адаптованої до кліматичних умов України. Зроблено розрахунок утриманого поверхневого стоку покрівлею німецького виробника компанії ZinCo. «Зелена» покрівля знаходиться у місті Києві. Площа покрівлі дорівнюе $150 \mathrm{~m}^{2}$. Встановлено, що покрівля ZinCo здатна утримати 7950 л дощової води і ичм самим зменшувати поверхневий стік, розвантаживши зливові колодязі. Ефективність покрівлі для зменшення поверхневого стоку сягає 21,2\%, шо є дуже хорошим показником. Очищена дощова вода з «зелених» покрівель може збиратися в резервуари $i$ використовуватися для технічних потреб. Для збору дощової води з інтенсивної плоскої покрівлі площею $150 \mathrm{M}^{2}$ для офісного колективу з 8 осіб необхідний резервуар об'ємом 4 м $^{3}$.

Ключові слова: поверхневий стік; «зелена» покрівля; дощова вода; накопичувальний резервуар

\section{Вступ}

Поверхневий стік з урбанізованих територій є одним із джерел забруднення природних вод. Запобігання впливу цього джерела забруднювачів на якість води поверхневих водойм $є$ одним із заходів із забезпечення екологічної безпеки держави. Саме ця мета вирішується сьогодні системою «зеленого» будівництва за допомогою нових екологічних перспективних «зелених» технологій. Однією з таких технологій є технологія «зелених» покрівель.

Технологія «зелених» покрівель використовується для кількісного та якісного регулювання дощових стоків. Якісне регулювання дощових стоків передбачає їхню фільтрацію та вторинне використання стічних вод, завдяки чому заощаджується цінний природний ресурс - вода.

Під поверхневим стоком розуміють процес переміщення вод атмосферного походження по земній поверхні (стікання дощових, талих і поливомийних вод) у водойми і пониження рельєфу під дією сили тяжіння. При розрахунках визначається величина стоку, що показує кількість води, яка стікає з водозбору за деякий інтервал часу.

Забруднення поверхневого стоку відбувається в результаті розчинення газів та пилу із приземних шарів атмосфери; змиву верхніх шарів грунту та зруйнованих дорожніх покриттів; змиву від сміттєконтейнерних майданчиків, забруднених органічними речовинами; промислових відходів у вигляді викидів; витоку нафтопродуктів; миття транспорту та ін.

Зміна погодних умов (наприклад, рясні опади) може призвести до короткочасного перевантаження міської каналізаційної системи. Великою перевагою «зелених» дахів є накопичення вологи, що дозволяє відстрочити стік зливової води, розвантажуючи при цьому каналізаційну систему i попереджаючи повені. 
Однак довільне збільшення накопичуваної води в стандартній структурі «зеленої» покрівлі неможливо, оскільки велика кількість вологи може згубно вплинути на рослинність. Проте, така опція доступна в системі дощової води на «зеленій» покрівлі в якості доповнення до інших систем озеленення.

Система збору дощової води на «зеленій» покрівлі дозволяє накопичити в середньому до 80 л/м² опадів, а потім протягом певного, визначеного заздалегідь періоду (від 24 годин до декількох днів) вивільнити воду в каналізаційну систему. Простір, необхідний для зайвої кількості опадів, створюється завдяки сітчастій прокладці, розташованій під фактичним «зеленим» дахом. Тим часом, елементи, які мають першочергове значення для належного функціонування «зеленого» даху (сховище води для рослин, повітряно-водний баланс в кореневій зоні тощо), залишаються без змін. Система збору дощової води може розташовуватися практично під всіма системами озеленення дахів, якщо це допускається конструкцією надбудови, від екстенсивної «зеленої» покрівлі до саду на даху з терасами та автомобільними дорогами. Якщо ж площа покрівлі не дозволяє повністю увібрати дощову воду - наприклад, під час затяжних зливових дощів, то вона все одно фільтрує воду, очищає їі та затримує на своїй поверхні. Воді потрібно більше часу, щоб дістатися до водостічних труб, в порівнянні з неозелененою покрівлею. Швидкий сход великих обсягів води небезпечний для районів, розташованих нижче, де зливова каналізація може не впоратися з підвищеним навантаженням.

Використання технологій «зелених» покрівель для кількісного та якісного регулювання дощових стоків набирає актуальності у багатьох країнах світу: Німеччині, Великобританії, Польщі, Франції, США та інших. Однак в Україні практично відсутні науково-технічні розробки та дослідження щодо «зелених» конструкцій та можливостей регулювання ними дощових стоків, методики щодо розрахунку вторинного використання дощових вод. Тому тема даної роботи є актуальною та перспективною для підвищення екологічної безпеки сучасних урбоценозів.

\section{Аналіз останніх досліджень і публікацій}

Однією 3 найважливіших екологічних переваг «зелених» покрівель для сучасних урбоценозів $є$ зменшення кількості стічних вод. Швидкий стік значної кількості зливової води 3 незамощених мостових і дахів має негативні наслідки. Зокрема, він викликає руйнівні повені [1], ерозію, забруднення й руйнування середовища перебування тварин. Здатність «зелених» покрівель зменшувати цей стік частково за рахунок його уповільнення, частково за рахунок накопичення в грунті давно і добре відома. «Зелена» покрівля забезпечує регулювання стоку за рахунок тих же заходів, що і звичайний водорегулювальний басейн.

У порівнянні 3 подібними способами регулювання дощового стоку, «зелена» покрівля недорога, не вимагає особливого догляду й надійна. «Зелені» покрівлі $є$ єдиним практичним способом контролю стоку в урбанізованих районах, що не вимагають додаткового будівництва. Рослинні покриття даху особливо ефективні в регулюванні швидкості стоку з великих дахів, таких як типові дахи комерційних або освітніх будівель. Вони можуть бути спроектовані так, щоб забезпечувати заданий рівень контролю зливового 
стоку, включаючи як зменшення загального річного обсягу стоку (50-60\% є звичайною величиною), так і швидкості пікового стоку [2, 3].

Надійна методика передбачення швидкості та кількості зливових стоків 3 рослинних покрівель була успішно використана в Німеччині, де вже існують великі системи 3 нульовим стоком. Ці системи в великій мірі засновані на «зелених» дахах. Наприклад, на будівлях Bondorf Transportation Center у Зіндельфінгені досягнуто повну відсутність скидання зливових стоків, в основному за рахунок використання $46000 \mathrm{~m}^{2}$ «зелених» покрівель.

«Зелені» покрівлі поглинають опади і, якщо води мало, вони повертають іiі в природний кругообіг шляхом випаровування, минаючи міську зливову каналізацію. Цей процес імітує природний спосіб поглинання і віддачі води лісами, який допомагає запобігти повені вниз за течією. Крім того, дощову воду можна збирати у резервуар і використовувати для побутових потреб. Будь-яка, навіть найменша «зелена» покрівля в змозі повністю увібрати шар води завтовшки близько $2,54 \mathrm{~cm}$.

Якщо ж площа покрівлі не дозволяє повністю увібрати дощову воду наприклад, під час затяжних зливових дощів, то вона все одно фільтрує воду, очищає іii i затримує на своїй поверхні. Воді потрібно більше часу, щоб дістатися до водостічних труб, в порівнянні 3 неозелененою покрівлею. Швидкий сход великих обсягів води небезпечний для районів розташованих нижче, де зливова каналізація може не впоратися 3 підвищеним навантаженням.

«Зелені» покрівлі захищають інші системи будівлі від впливу води. У більшості приватних володінь дах займає близько 40\% плями забудови, а значить, за допомогою озелененої покрівлі є можливість затримати більшу частину падаючої на ділянку води і запобігти пошкодженню саду або мощених доріжок.

Поверхня неозелененої покрівлі далека від ідеальної чистоти, оскільки на ній осідає абсолютна більшість забруднювачів з атмосфери. При сильному зливі потік брудної води спрямовується вниз, накопичуючись в найнижчих точках ландшафту. «Зелені» покрівлі частково можуть нейтралізувати шкідливі викиди $[4,5]$.

В районі Берліна у Potsdamer Platz для зменшення забруднення річки Шпрее були масштабно використані екстенсивні «зелені» покрівлі. Ця програма продемонструвала, що екстенсивні «зелені» покрівлі можуть значно зменшувати кількість органіки, яка змивається 3 дахів, але, разом 3 тим, показала і важливість правильного вибору рослинного середовища і рослин [4]. Ринок будівництва «зелених» дахів у Польщі є відносно молодий. Тому там також існує потреба в дослідженнях, щодо можливості управління дощовими потоками завдяки «зеленим» покрівлям у національних умовах. Результати дослідження, проведеного в дослідницьких центрах у Вроцлаві, показують, що відтоки з «зелених» покрівель можна відкласти до декількох годин від початку опадів. На підставі даних, отриманих у Вроцлавському університеті екології та природокористування, встановлено, що збереження води «зеленими» дахами залежить від погодних умов. За даними польських вчених, цей процес значно покращується, коли попередня суха погода триває довше, ніж один день, а кількість опадів не перевищує 10 мм на добу [5].

Перевага «зелених» покрівель в урбоценозах не тільки в зменшенні навантаження на зливову каналізацію і фільтрації стічних вод. Очищена 
дощова вода 3 «зелених» покрівель може збиратися в резервуари i використовуватися для технічних потреб (змивів туалетів, роботи пральних машин, садового використання, миття машин тощо) [6, 7]. У зв'язку із зростанням тарифів на водопостачання, використання дощової води стає все більш виправданим. Німці вважають, що незабаром застосування дощової води буде таким же звичайним явищем, як поділ відходів, 60\% питної води можна заощадити, застосовуючи дощову воду. Ці кошти можуть бути використані на інші цілі. Але більш важливим $є$ збереження води, найбільш цінного ресурсу. Екологічні технології німецької компанії Wilo [8] мають найкращу у світі репутацію в області застосування дощової води. Дана компанія розробила довідковий посібник 3 використання дощової води. У цьому посібнику наведено приклади розрахунків припливу дощової води, визначення потреб у воді, розрахунок обсягу бака для зберігання дощової води та вибір системи водопостачання. Крім того, цікавим і цінним є введення коефіцієнта стоку $(c)$ для різних типів поверхонь покрівель, в тому числі для інтенсивних i екстенсивних «зелених» покрівель. В українському ДБН В.2.6-14-97 [9] та ДБН В.2.6-220:2017 [10] така методика відсутня.

Один із лідерів німецьких досліджень «зелених» дахів д-р Ганс-Йоахім Ліске (Dr. Hans-Joachim Liesecke), у своїй книзі «Збереження зелених дахів» (Das Retentionsvermugen von Dachbegrunungen), обговорює їхні потенційні можливості для утримання води. Сумарне випаровування грає найважливішу роль у здатності «зелених» дахів утримувати воду, і затримка води в літні місяці значно більша, ніж у зимові, тому що в літній сезон швидкість евапотранспірації набагато вище $[11,12]$. Таким чином, в районах, де велика частина опадів припадає на зимові місяці, «зелені» дахи можуть бути не настільки ефективними, оскільки в зимовий період має місце менша затримка води. Отже, ефективність зростає у тих регіонах, де значна кількість опадів припадає на теплий період.

У Німеччині, де випадає приблизно 580 мм опадів на рік, сумарне випаровування становить близько 64 мм/рік 3 більш низькою евапотранспірацією в січні (близько 0,3 мм/місяць) і набагато більш високою швидкістю евапотранспірації в липні - 12 мм/місяць. В іншому дослідженні Ліске випробував різні грунти екстенсивних «зелених» дахів глибиною від 80 мм до 120 мм. Вивчалися «зелені» дахи з важкими і легкими грунтами, деякі 3 дренажними шарами, деякі без них, і кожний «зелений» дах мав ухил у $5^{\circ}$, за винятком одного з ухилом $0^{\circ}$. Дані за трирічний період спостережень 31995 по 1997 рік показують, що кількість опадів була 918 мм, 712 мм і 827 мм в 1995, 1996 i 1997 рр. відповідно [11]. Для звичайних дахів у ці роки затримання води варіювало в діапазоні від 10\% до 20\%, тоді як затримка води «зеленими» дахами коливалася від 50\% до 65\% [11]. Це дослідження надало німецьким компаніям свого роду загальні галузеві стандарти щорічного утримання води «зеленими» дахами. Наприклад, річна затримка води для «зелених» дахів $32^{\circ}$ ухилом і глибиною грунтового шару 20-40 мм становить 40-45\%, при глибині грунтового шару 60-80 мм становить 50-55\%, а з глибиною грунту 100-120 мм складає 55-60\% [12].

Ліске також навів результати, що показують здатність «зелених» покрівель зменшувати піковий зливовий стік 3 дахів. В іншому дослідженні, проведеному в Німеччині, стік зі звичайною даху, покритого гравієм, порівнювався зі стоком з екстенсивного «зеленого» даху при товщині грунту 
40 мм. Через 15 хвилин після початку опадів стік зі звичайного даху склав 20 мм з 27 мм загальної кількості опадів і тільки 0,043 мм з «зеленого» даху [12]. У той час як зі звичайних дахів стікає 74\% від загальної кількості опадів, 3 «зелених» дахів за той же час стікає тільки 16\%. Залишок стоку з «зеленого» даху буде або збережений для використання рослинністю, або повільно покине грунт. Це переконливо показує можливість зниження пікового стоку за допомогою «зелених» дахів.

Німецький дослідник Шейд [13] вважає, що на швидкість стоків 3 тонкошарових екстенсивних «зелених» дахів впливає ухил дахів. Дахи 3 ухилом до $30^{\circ}$ мають більший об’єм стоків за менший час, ніж плоскі дахи.

Дослідження утримання води «зеленими» дахами були проведені також в США, в місті Портланд (штат Орегон). Здатність «зелених» дахів утримувати воду залежить від цілого ряду чинників, таких як інтенсивність опадів, їх сезонні коливання, рівень евапотранспірації та вологості грунту на даху. Під час 15-місячного періоду спостережень (2002-2003 рр.), затримка води 3 екстенсивної «зеленої» покрівлі з глибиною грунту 100-120 мм склала 69\% від загальної кількості опадів [14]. Протягом декількох місяців 3 травня 2002 року по жовтень 2002 року, понад 90\% місячних опадів було затримано «зеленим» дахом, проте це були сухі місяці року з кількістю опадів менше ніж 50 мм протягом кожного місяця [14]. Значне утримання опадів спостерігалося також протягом вологих зимових місяців в Портланді. Хатчінсон та ін. [14] повідомляють про утримання приблизно 30\% опадів в січні 2002 року, утримання 50\% в грудні 2002 року і утримання 60\% в березні 2003 року при місячній кількості опадів близько 160 мм, 108 мм і 127 мм за кожен місяць, відповідно.

Результати цього дослідження показують, що більша кількість опадів взимку може призвести до зниження затримування, а більш високі швидкості випаровування навесні можуть привести до більшого утримування. Це дослідження продемонструвало також зниження пікового стоку з «зеленого» даху на 80\%. Пікова зливова витрата для обраних злив у 2002 і 2003 роках варіювала від 1,2 до $5,5 \mathrm{~m}^{3} / \mathrm{c}$, а відповідний піковий стік варіював від 2,3 до $3,4 \mathrm{~m}^{3} / \mathrm{c}[10,11]$.

Систематичні дослідження були проведені колективом авторів у Боготі (Колумбія) [15]. Досліджувалися стічні води 3 горизонтальної та похилої покрівлі 3 різними видами субстрату, не засаджені та засаджені різними видами рослин. Серед результатів слід відзначити зростання на $10 \%$ поглинання води при засадженні рослинами порівняно з грунтом без рослин, різниця у 65\% між утриманням води різними субстратами та значний ефект покращення складу стічних вод.

Група канадських учених [16] виконали статистичний аналіз впливу кліматичних факторів різних регіонів земної кулі на властивість «зелених» покрівель утримувати та утилізувати дощову воду та отримали графічні та табличні дані для проектування цих конструкцій у різних країнах.

Таким чином, проаналізувавши зазначені літературні дані, ми можемо сказати, що дослідження щодо очищення та накопичення дощової води «зеленими» покрівлями мають велику актуальність у багатьох країнах світу.

Мета роботи. Дослідження впливу поверхневого стоку на навколишнє середовище та зменшення його негативного впливу за допомогою «зелених» покрівель. 


\section{Завдання роботи:}

1. Провести аналіз існуючих теоретичних і практичних підходів щодо можливостей використання «зелених» покрівель для кількісного та якісного регулювання дощових стоків.

2. Провести оцінку об'єкта дослідження.

3. Здійснити пошук та удосконалення методик дослідження.

4. Зробити експериментальні розрахунки утриманого поверхневого стоку покрівлею німецького виробника та резервуару для зберігання дощової води 3 інтенсивної «зеленої» покрівлі.

\section{Методика дослідження}

Розрахунок утриманого поверхневого стоку покрівлею німецького виробника здійснювався за оригінальною авторською методикою [17].

Розрахунок об'єму резервуара здійснювався за удосконаленою автором методикою на базі методики Wilo, адаптованої до кліматичних умов України. Згідно з даними ДСТУ Н Б В.1.1-27:2010 річна кількість опадів для даного регіону - $522 \mathrm{mм} /$ рік [18]. Максимальна середньомісячна кількість опадів припадає на червень (30 днів) і становить 66 мм/міс.

\section{Результати дослідження}

Розрахунок утриманого поверхневого стоку. Зроблено розрахунок утриманого поверхневого стоку покрівлею німецького виробника. «Зелена» покрівля виробництва фірми ZinCo розташована на перехресті проспекту Лобановського і вулиці Андрія Головка (м. Київ). Площа покрівлі дорівнює $150 \mathrm{~m}^{2}$. За даними виробника водоутримуюча здатність матеріалів, 3 яких складається «зелена» покрівля, наступна:

1. Системний субстрат $-4 \pi / \mathrm{M}^{2}$.

2. Вологоутримуючий захисний мат SSM-50 - 5 л/ $\mathrm{M}^{2}$.

3. Захисний мат SSM-45 - 4 л/ $\mathrm{M}^{2}$.

4. Дренажна і водонакопичувальна система Floradrain FD-40-E - 40 л/ $\mathrm{m}^{2}$.

Виходячи $з$ цих даних, ми можемо порахувати загальну кількість утриманої води всіма елементами покрівлі на $\mathrm{M}^{2}$, дм³ $^{3} \mathrm{M}^{2}$ :

$$
Q_{\Sigma}=Q_{1}+Q_{2}+\ldots+Q_{n}
$$

де $Q_{1}, Q_{2}, \ldots, Q_{n}$ - кількість утриманої води елементом системи $1,2, \ldots, n$.

Тоді $Q_{\Sigma}=4+5+4+40=53$ дм $^{3} / \mathrm{M}^{2}$.

Розрахунок загальної кількості утриманої води всією покрівлею, дм³:

$$
Q_{\Sigma, H_{2} O}=Q_{\Sigma} \cdot S
$$

де $S$ - площа даху, м². Тоді

$$
Q_{\Sigma, H_{2} O}=53 \cdot 150=7950 \text { дм }^{3} .
$$


За підрахунками на перехресті проспекту Лобановського і вулиці Андрія Головка в період інтенсивного випадіння дощу може випадати 20-30 мм опадів (30 літрів на $\mathrm{M}^{2}$ ). Загальна площа перехрестя $1500 \mathrm{~m}^{2}$.

Розрахунок загальної кількості опадів на перехресті:

$$
Q_{\Sigma, \text { nep }}=Q_{\text {cep }} \cdot S
$$

де $Q_{c e p}-$ середня кількість опадів, мм. Тоді

$$
Q_{\Sigma, \text { nep }}=1500 \cdot 25=37500 \text { дм }^{3} .
$$

Таким чином, покрівля німецької фірми ZinCo здатна утримати 7950 дм $^{3}$ дощової води і цим самим зменшити поверхневий стік, розвантаживши зливові колодязі.

Ефективність покрівлі для зменшення поверхневого стоку сягає 21,2\%, що $\epsilon$ дуже хорошим показником. Для всього проспекту Лобановського потрібно приблизно 4 об' єкти «зеленого» будівництва 3 площею «зеленої» покрівлі не менше $100 \mathrm{~m}^{2}$ для врегулювання поверхневого стоку. Хоча це не вирішить проблему у всьому Києві, але якщо збільшувати кількість таких об'єктів «зеленого» будівництва, $\epsilon$ шанс зовсім забути про затоплення вулиць у м. Київ.

Якісне регулювання дощових стоків «зеленими» покрівлями. Технологія «зелених» покрівель використовується для кількісного та якісного регулювання дощових стоків. Якісне регулювання дощових стоків передбачає їхню фільтрацію та вторинне використання стічних вод, завдяки чому заощаджується цінний природний ресурс - вода.

Згідно з даними ДСТУ Н Б В.1.1-27:2010 річна кількість опадів для даного регіону - 522 мм/рік [18]. Максимальна середньомісячна кількість опадів припадає на червень (30 днів) і становить 66 мм/міс.

\section{1. Розрахунок кількості опадів:}

Кількість опадів на місяць на одиницю площі: $q=66$ дм³ $^{3} \mathrm{M}^{2}$;

Площа збору: $S=150 \mathrm{~m}^{2}$;

Коефіцієнт стоку $c=0,5$ [8] (дані щодо коефіцієнта стоку різняться залежно від конструкції покрівель, кліматичних умов (впливають на випаровування) та фітоценозу [19];

Кількість днів у місяці $z_{M}=30$ діб.

Максимальна місячна витрата дощової води, дм³/міс:

$$
Q_{p}=q \cdot S \cdot c
$$

За формулою (4)

$$
Q_{p}=66 \cdot 150 \cdot 0,5=4950 \text { дм }^{3} / \text { міс. }
$$

Середньодобова витрата дощової води у місяці максимальних опадів (червень), дм³/добу:

$$
Q=\frac{Q_{p}}{z_{M}} .
$$


За формулою (5)

$$
Q=\frac{4950}{30}=165 \text { дм³ }^{3} \text { добу. }
$$

\section{2. Розрахунок потреб у дощовій воді:}

на одну людину:

зливний бачок туалету без економної кнопки: 14 м³/рік [8];

пральна машина: $6 \mathrm{~m}^{3} /$ рік [8];

кран для миття (прибирання): $1 \mathrm{~m}^{3} /$ рік [8];

всього $q_{л}=14+6+1=21 \mathrm{~m}^{3} /$ рік;

на всіх мешканців будинку $(n=8$ осіб)

$$
Q_{p, \text { потр }, \pi}=n \cdot q_{л}=8 \cdot 21=168 \mathrm{~m}^{3} / \text { рік; }
$$

на полив саду площею $S_{c}=25 \mathrm{~m}^{2}$ з потребою $q_{c}=0,06 \mathrm{~m}^{3} /\left(\mathrm{м}^{2} \cdot\right.$ рік) [8]

$$
Q_{p, \text { nomp }, c}=S_{c} \cdot q_{c}=25 \cdot 0,06=1,5 \mathrm{~m}^{3} / \mathrm{pi \kappa}
$$

на полив «зеленої покрівлі» площею $S_{n}=150$ м $^{2} 3$ тією ж потребою

$$
Q_{p, \text { nomp }, n}=S_{n} \cdot q_{c}=150 \cdot 0,06=9 \mathrm{~m}^{3} / \text { рік; }
$$

Сумарні потреби на полив:

$$
Q_{p, \text { потр }, \text { nл }}=Q_{p, \text { потр }, c}+Q_{p, \text { потp }, n}=1,5+9=10,5 \mathrm{~m}^{3} / \mathrm{pi \kappa}
$$

Сумарні потреби на будинок і полив:

$$
Q_{p, \text { nomp }}=Q_{p, \text { nomp }, n}+Q_{p, \text { nomp }, \text { nл }}=168+10,5=178,5 \mathrm{~m}^{3} / \mathrm{pi \kappa} ;
$$

Щоденні потреби при сезоні поливу садів (орієнтовно $z_{c}=243$ доби), $\mathrm{M}^{3} /$ добу

$$
Q_{\text {nomp }}=\frac{Q_{p, \text { nomp }, \pi}}{365}+\frac{Q_{p, n o m p, n л}}{z_{c}} .
$$

За формулою (6)

$$
Q_{\text {nотр }}=\frac{168}{365}+\frac{10,5}{243}=0,5035, \mathrm{~m}^{3} / \text { добу. }
$$




\section{3. Розрахунок резервуара}

Досвід показує, що об'єм резервуара для зберігання 2-3 тижневого запасу води $є$ оптимальним. Більший обсяг призводить до погіршення якості води, менший - до більшого використання питної води. Приймаємо час накопичення води 3 тижні або $z=21$ доба;

Потрібний об'єм резервуара за наявною дощовою водою, м ${ }^{3}$

$$
W_{\text {nomp }}=\frac{Q \cdot z}{1000}
$$

За формулою (7)

$$
W_{\text {nomp }}=\frac{165 \cdot 21}{1000}=3,47 \mathrm{M}^{3}
$$

Час споживання отриманого об'єму води становитиме

$$
Z=\frac{W_{\text {nотр }}}{Q_{\text {nотр }}}, \text { діб. }
$$

За формулою (8)

$$
Z=\frac{3,47}{0,5035}=7 \text { діб. }
$$

Оскільки час споживання води відповідає рекомендованому (не більше 3 тижнів), приймаємо до установки резервуар об'ємом $4 \mathrm{~m}^{3}$. У разі перевищення часу споживання (3 тижні) отриманий об'єм бака зменшують (у разі швидкого споживання води залишають отриманий об 'єм бака або за наявності коштів замовника збільшують його в надї на можливе перевищення норми опадів, але не більше 0,5035·21 = 10,57 $\mathrm{M}^{3}$ ).

Таким чином, важливими екологічними та економічними перевагами «зелених» покрівель в сучасних урбоценозах є: зменшення кількості стічних вод за рахунок випаровування і вбирання вологи рослинами; поліпшення якості стічних вод за рахунок природної фільтрації; зменшення навантаження на зливові каналізації за рахунок зниження швидкості водного потоку.

Очищена дощова вода 3 «зелених» покрівель може збиратися в резервуари i використовуватися для технічних потреб. Для збору дощової води 3 інтенсивної плоскої покрівлі площею $150 \mathrm{~m}^{2}$ для офісного колективу з 8 осіб необхідний резервуар об'ємом 4 м $^{3}$. При цьому сумарні потреби на будинок i полив саду становлять $178,5 \mathrm{~m}^{3} /$ рік, а щоденні потреби - 0,5035 м³/добу.

\section{Висновки та перспективи подальших досліджень}

Важливими екологічними та економічними перевагами «зелених» покрівель у сучасних урбоценозах $\epsilon$ : Зменшення кількості стічних вод за рахунок випаровування і вбирання вологи рослинами; поліпшення якості стічних вод 
за рахунок природної фільтрації; зменшення навантаження на зливову каналізацію за рахунок зниження швидкості водного потоку. Покрівля ZinCo здатна утримати 7950 л дощової води і цим самим зменшувати поверхневий стік, розвантаживши зливові колодязі. Ефективність покрівлі для зменшення поверхневого стоку сягає $21,2 \%$, що є дуже хорошим показником. Очищена дощова вода 3 «зелених» покрівель може збиратися в резервуари i використовуватися для технічних потреб. Для збору дощової води 3 інтенсивної плоскої покрівлі площею $150 \mathrm{~m}^{2}$ для офісного колективу з 8 осіб необхідний резервуар об'ємом $4 \mathrm{~m}^{3}$.

На карті Києва позначені 208 проблемних місць, де постійно накопичуються великі об'єми води. У подальшому планується розрахувати кількість «зелених» конструкцій для мінімізації критичної ситуації.

\section{СПИСОК ЛІТЕРАТУРИ}

1.Mora-Melià, D. Viability of Green Roofs as a Flood Mitigation Element in the Central Region of Chile. / D. Mora-Melià, C. S. López-Aburto, P. Ballesteros-Pérez, P. MuñozVelasco // Sustainability. - 10, 2018. - P. 1130. DOI: 10.3390/su10041130.

2. Озеленённые крыши: 4 пути управления дождевой водой. - 21.03.2015. [Электронный ресурс]. - Режим доступа: http://www.krovlirussia.ru/\%D0\%B1\%D0\% B5\%D0\%B7-\%D1\%80\%D1\%83\%D0\%B1\%D1\%80\%D0\%B8\%D0\%BA\%D0\%B8/roofdigest/ozelenennye-kryshi-4-puti-upravleniya-dozhdevoj-vodoj.

3. Mentens, J. Green Roofs as a Tool for Solving the Rainwater Runoff Problem in the Urbanized 21 st Century? / J. Mentes, D. Raes, M. Hermy // Landscape and Urban Planning. 77 (3), 2006. - P. 217-226. DOI: 10.1016 / j.landurbplan.2005.02.010.

4. VanWoert, N.D. Green Roof Stormwater Retention: Effects of Roof Surface, Slope, and Media Depth. / N.D. VanWoert, D.B. Rowe, J.A. Andresen, C.L. Rugh, R.T. Fernandez, L. Xiao // Journal of Environmental Quality. - 34 (3), 2005. - P. 1036-1044. DOI: 10.2134.

5. Burszta-Adamiak, E. Zielone dachy jako rozwiązania poprawiające gospodarkę wodami opadowymi w miastach. / E. Burszta-Adamiak, J. Łomotowski, P. Wiercik // Inżynieria Ekologiczna. - 39, 2014. - P. 26-32.

6. Vijayaraghavan, K. A. A fieid study to evaluate runoff quality from green roofs. / K. A. Vijayaraghavan, U. M. Joshi, R. Balasubramanian // Water research. - 46, 2012. P. 1337-1345.

7. Cipolla, S. S. Decentralized Water Management: Rainwater Harvesting, Greywater Reuse and Green Roofs within the GST4Water Project. / S. S. Cipolla, M. Altobelli, M. Maglionico // Proceedings. - 2, 2018. - P. 673-680. DOI:10.3390/proceedings2110673.

8. Wilo - Использование дождевой воды - справочное пособие. - 04.2016. [Электронный ресурс]. - Режим доступа: https://atislab.ru/upload/doc/wilo/Brochure_ rainwater_205x297_RU.pdf

9. ДБН В.2.6-14-97 Покриття будинків і споруд (з поправкою, опублікованою в журналі «Будівництво України», 2002, № 4, с. 42). - Київ, 1998. - 108 с.

10. ДБН В.2.6-220:2017 Покриття будівель і споруд. - Київ: Міністерство регіонального розвитку, будівництва та житлово-комунального господарства України, 2017. $-46 \mathrm{c}$.

11. Liesecke, H-J. Extensive Begrunung bei 5o Dachneigung. // Stadt Und Grun. - 48 (5), 1999. - P. 337-346.

12. Liesecke, H-J. Das Retentionsvermцgen von Dachbegrunungen. // Stadt Und Grun. 47 (1), 1998. - P. 46-53.

13. Schade, C. Wasserruckhaltung und Abflussbeiwerte bei dunnschichtigen Extensivbegrunungen. // Stadt Und Grun. - 49 (2), 2000. - P. 95-100. 
14. Hutchinson, D. Stormwater Monitoring Two Ecoroofs in Portland, Oregon, USA. In Proc. Greening Rooftops for Sustainable Communities. Chicago / D. Hutchinson, P. Abrams, P. Retzlaff, T. Liptan. - May 29-30, 2003, Chicago, Illinois.

15. Ferrans, P. Effect of Green Roof Configuration and Hydrological Variables on Runoff Water Quantity and Quality. / P. Ferrans, C.V. Rey, G. Pérez, J. P. Rodríguez, M. DíazGranados // Water. - 10, 2018. - P. 960-977. DOI:10.3390/w10070960.

16. Akther, M. A Review of Green Roof Applications for Managing Urban Stormwater in Different Climatic Zones. / M. Akther, J. He, A. Chu, J. Huang, B. Van Duin // Sustainability. 10, 2018. - P. 2864-2891. DOI:10.3390/su10082864.

17. Tkachenko, T. The reuse of rainwater drains by using «green roofs». // USEFUL. - 3 (1), 2019. - P. 01-05. DOI: https://doi.org/10.32557/useful-3-1-2019-0001.

18. ДСТУ - Н Б В. 1.1 - 27:2010 Будівельна кліматологія. - Київ: Укрархбудінформ, 2011. $-123 \mathrm{c}$.

19. Herrera, J. Using a Hydrological Model to Simulate the Performance and Estimate the Runoff Coefficient of Green Roofs in Semiarid Climates. / J. Herrera, G. Flamant, J. Gironás, S. Vera, C.A. Bonilla, W. Bustamante, F. Suárez // Water. - 10(2), 2018. - P. 198-214. DOI:10.3390/w10020198.

Стаття надійшла до редакиії 13.05.2020 і прийнята до друку після рещензування 28.07.2020

\section{REFERENCES}

1.Mora-Melià, D., López-Aburto, C. S., Ballesteros-Pérez, P., \& Muñoz-Velasco, P. (2018). Viability of Green Roofs as a Flood Mitigation Element in the Central Region of Chile. Sustainability, 10, 1130. DOI: 10.3390/su10041130.

2. Ozelenennye kryshi: 4 puti upravleniya dozhdevoj vodoj [Green roofs: 4 ways to manage rainwater]. (21 March 2015). Retrieved 14 April 2020 from http://www.krovlirussia.ru/\%D0\%B1\%D0\%B5\%D0\%B7-\%20\%D1\%80\%D1\%83\%D0\%B1 $\% \mathrm{D} 1 \% 80 \% \mathrm{D} 0 \% \mathrm{~B} 8 \% \mathrm{D} 0 \% \mathrm{BA} \% \mathrm{D} 0 \% \mathrm{~B} 8 /$ roof-digest/ozelenennye-kryshi-4-puti-upravleniyadozhdevoj-vodoj. (in Russian)

3. Mentens, J., Raes, D., \& Hermy, M. (2006). Green Roofs as a Tool for Solving the Rainwater Runoff Problem in the Urbanized 21 st Century? Landscape and Urban Planning, 77(3), 217-226. DOI: 10.1016 / j.landurbplan.2005.02.010.

4. VanWoert, N.D., Rowe, D.B., Andresen, J.A., Rugh, C.L., Fernandez, R.T., \& Xiao, L. (2005). Green Roof Stormwater Retention: Effects of Roof Surface, Slope, and Media Depth. Journal of Environmental Quality, 34 (3), 1036-1044. DOI: 10.2134.

5. Burszta-Adamiak, E., Łomotowski, J., \& Wiercik, P. (2014). Zielone dachy jako rozwiązania poprawiające gospodarkę wodami opadowymi w miastach [Green roofs as a tool for improvement the stormwater management in urban areas]. Inżynieria Ekologiczna, 39, 26-32. (in Polish)

6. Vijayaraghavan, K. A., Joshi, U. M., \& Balasubramanian, R. (2012). A fieid study to evaluate runoff quality from green roofs. Water research, 46, 1337-1345.

7. Cipolla, S. S., Altobelli, M., \& Maglionico, M. (2018). Decentralized Water Management: Rainwater Harvesting, Greywater Reuse and Green Roofs within the GST4Water Project. Proceedings, 2, 673-680. DOI:10.3390/proceedings2110673.

8. Wilo - Ispolzovanie dozhdevoj vodye - spravochnoe posobie [Wilo - Using Rainwater a reference guide]. (2016). Retrieved 14 April 2020 from https://atislab.ru/upload/doc/wilo/Brochure_rainwater_205x297_RU.pdf. (in Russian)

9. DBN B.2.6-14-97 Pokryttij budivel i sporud (z popravkoyu, opublikovanoyu u zhurnali "Budivnyztvo Ukrajny", 2002, 4, p. 42) [DBN B.2.6-14-97 Covering of Buildings and Structures (as amended in the journal "Construction of Ukraine", 2002, No. 4, p. 42)]. (1998). Kyiv. (in Ukrainian) 
10. DBN B.2.6-220:2017 Pokryttij budivel i sporud [DBN B.2.6-14-97 Covering of Buildings and Structures]. (2017). Kyiv. (in Ukrainian).

11. Liesecke, H-J. (1999). Extensive Begrunung bei 5o Dachneigung. Stadt Und Grun, 48 (5), 337-346. (in German).

12. Liesecke, H-J. (1998). Das Retentionsvermugen von Dachbegrunungen. Stadt Und Grun, 47 (1), 46-53. (in German).

13. Schade, C. (2000). Wasserruckhaltung und Abflussbeiwerte bei dunnschichtigen Extensivbegrunungen. Stadt Und Grun, 49 (2), 95-100. (in German).

14. Hutchinson, D., Abrams, P., Retzlaff, P., \& Liptan, T. (2003). Stormwater Monitoring Two Ecoroofs in Portland, Oregon, USA. In Proc. Greening Rooftops for Sustainable Communities. Chicago, May 29-30, Chicago, Illinois.

15. Ferrans, P., Rey, C.V., Pérez, G., Rodríguez, J. P., \& Díaz-Granados, M. (2018). Effect of Green Roof Configuration and Hydrological Variables on Runoff Water Quantity and Quality. Water, 10, 960-977. DOI:10.3390/w10070960.

16. Akther, M., He, J., Chu, A., Huang, J., \& Van Duin, B. (2018). A Review of Green Roof Applications for Managing Urban Stormwater in Different Climatic Zones. Sustainability, 10, 2864-2891. DOI:10.3390/su10082864.

17. Tkachenko, T. The reuse of rainwater drains by using «green roofs». (2019). "USEFUL", 3(1), 01-05. (in Ukrainian). DOI: https://doi.org/10.32557/useful-3-1-2019-0001.

18. DSTU - N B V. 1.1- 27:2010 Budivelna klimatologija [DSTU - N B. V. 1.1 - 27: 2010 Building climatology]. (2011). Kyiv: Ukrarchbudinform. (in Ukrainian).

19. Herrera, J., Flamant, G., Gironás, J., Vera, S., Bonilla, C.A., Bustamante, W., \& Suárez, F. (2018). Using a Hydrological Model to Simulate the Performance and Estimate the Runoff Coefficient of Green Roofs in Semiarid Climates. Water, 10(2), 198-214. DOI:10.3390/w10020198.

The article was received 13.05.2020 and was accepted after revision 28.07.2020

\section{Ткаченко Тетяна Миколаївна}

доктор технічних наук, доцент, професор кафедри охорони праці та навколишнього середовища Київського національного університету будівництва і архітектури

Адреса робоча: 03037 Україна, м. Київ, проспект Повітрофлотський, 31

ORCID: orcid. org/ 0000-0003-2105-5951e-mail: tkachenkoknuba@ gmail.com

\section{Прокопенко Іван Олександрович}

студент 2-го курсу кафедри охорони праці та навколишнього середовища Київського національного університету будівництва і архітектури

Адреса робоча: 03037 Україна, м. Київ, проспект Повітрофлотський, 31

e-mail: vanya.prokopenko.2001@gmail.com 